\title{
Analysis of the Effect of Blood Sugar, Calcium, Chloride lons, and Blood Urea Nitrogen on Skin Wrinkles
}

Hyun Sun Noh, Moon Ju Kim

Department of Beauty and Arts, DongBang Culture University, Seoul, Korea

*Corresponding author: Moon Ju Kim, Department of Beauty and Arts, DongBang Culture University, 60, Seongbuk-ro 28-gil, Seongbuk-gu, Seoul 02838, Korea

Tel.: +82 28554952

Email: jackie8185@naver.com

Received December 30, 2020

Revised January 29, 2021

Accepted February 2, 2021

Published March 30, 2021

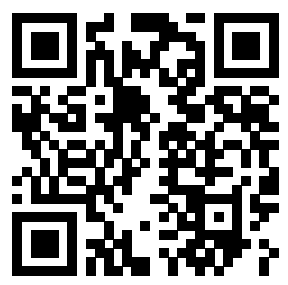

\begin{abstract}
Purpose: The purpose of this study was to statistically verify the effects of blood glucose, blood urea nitrogen (BUN), calcium, and chloride ions on the facial wrinkles of premenopausal women. Methods: Premenopausal women were recruited through the internet to be study participants. Those who had disease or who consumed drugs or health foods such as ginseng were excluded. The levels of blood glucose, BUN, calcium, and chloride ions were obtained, and facial wrinkles were measured with a skin meter. Multiple regression analysis was performed to evaluate the effects of blood glucose, BUN, calcium, and chloride ions on face wrinkles. Results: After excluding 13 people whose blood measurement variables deviated from the outliers, statistical analysis was performed for the remaining 64 participants. Analysis revealed the nonstandardization coefficient of blood glucose to be 0.019 and the significance probability was $p=0.027$. The nonstandardized coefficient of BUN was 0.108 , and the significance probability was $p=0.006$, which means that when BUN increased by $1 \mathrm{mg} / \mathrm{dL}$, wrinkles increased by 0.108 . The explanatory power of R2 was 0.203. Conclusion: This is the first report to reveal, based on empirical data, that blood glucose and BUN, which are known factors affecting cardiovascular disease and diabetes, also affect facial wrinkles.
\end{abstract}

Keywords: Blood glucose, Blood urea nitrogen, Calcium cation, Chloride anion, Wrinkle

\section{Introduction}

외면적인 모습은 자기 수용과 사회적 삶에 매우 중요한 요소이다. 노화가 된 모습은 높은 사망률과 관련되어 있어서 단지 외모 이상 의 의미를 함축한다(Christensen et al., 2009). 특히 얼굴모습은 노 화를 알려주는 대표적인 지표로 피부, 입술높이, 색소반점 등 다양 한 요소에 의해 영향을 받는다(Gunn et al., 2009; Nkengne et al., 2008). 다양한 외부적 요인이 얼굴모습에 영향을 미칠 수 있는데, 사 회적 지위, 흡연, 태양광선에 조사 등이다(Rexbye et al., 2006). 얼 굴모습 중 피부는 인간의 사회-문화적 관계에 영향을 미치는 첫번째 요소이다. 피부는 감정적인 표현 뿐만 아니라 개인의 건강상태와 웰 빙상태를 드러내는 매체이기도 하다. 피부의 색, 투명성, 수분수준은 심리적, 생리적 상태의 신호를 전달한다. 주름살은 노화라는 자연스 러운 삶의 과정 속에서 나타나며 피부표면의 고랑이라고 할 수 있다. 이것은 콜라겐의 손실, 피부의 탄력성의 감소, 피부의 재생산속도의
저하 등으로 인해 발생한다(Draelos et al., 2011). 피부의 노화는 내 적요인과 외적요인이 있다. 내적요인은 개인의 유전적인 배경에 기 인하는 것으로 개인의 행동으로 바꿀 수 없는 것이다. 반면 외적요인 은 흡연, 태양광, 영양상태, 알코올 섭취 등과 같은 개인의 행동에 기 인하는 것으로 의식적으로 변화 시킬 수 있다(Baumann, 2007).

오늘날 식이보충물이나 피부를 통한 화장품에 의해 영양적인 결 핍을 보완하는 경향이 있다. 외부로부터 뿐만 아니라 내부로부터 피 부건강을 돕는 시장이 급속히 증가하고 있다. 소비자들은 보다 효 과가 있을 뿐만 아니라 안전한 미용식품과 약용식품에 대해 관심 을 가지고 있다(Morganti et al., 2009). 대표적인 예가 영양화장품 (nutritional cosmetics)으로 이것은 입으로 섭취하는 식이 성분이 보 다 건강하고 보다 아름다운 피부를 만드는데 도울 수 있다는 개념이 다. 영양화장품은 기능성음료(functional beverages), 식이보충제 (dietary supplements), 기능성식품(functional foods)를 포함한다. 2006년 데이터모니터 리포트(Datamonitor report)의 "영양을 통한 
미용찾기(Seeking Beauty Through Nutrition"에 의하면 2005년 미 국에서 7억4천2백만 달러, 프랑스 2 억2천4백만달러, 독일 1 억6천2 백만달러, 영국 9천5백만 달러 등이 식이를 통한 미용 시장을 차지 하고 있었다. 식이를 통한 미용보충제판매는 2010년 7\%에서 $12 \%$ 까 지 성장하였다(Tabor \& Blair, 2009).

인체의 3 대 영양소인 탄수화물, 단백질, 지질과 비타민과 미네랄 들은 인체의 주성분이자 에너지원으로 핵심적 요소이다. 하지만 일 상생활 속에서 신체내의 혈액지표로서 영양소가 인체의 피부 주름에 미치는 영향에 대한 실증적이고 통합적인 연구는 질적으로 양적으로 매우 제한되어 있었다. 이러한 상황에서 본 연구에서는 피부미용 중 에서도 특히 3 대 영양소를 중심으로 주름과 관련된 영향력을 혈액지 표와 피부측정으로 통해 실증적으로 인과관계를 분석하고자 하였다. 이를 통해 일상의 식생활 속에서뿐만 아니라 다양한 먹는 화장품들 의 상품에서 기본 영양소의 밸런스를 적절히 맞출 수 있고 피부주름 을 취소화할 수 있는 기초자료로 활용하고자 하였다.

\section{1. 피부와 콜라겐}

피부는 무게와 면적에서 가장 큰 기관으로 인체말초의 센서로 서 바깥에 있는 뇌(brain on the outside)로 여겨지고 있다(Tobin, 2006). 인체 외부환경에 대한 1 차적 접촉점을 가지기에 피부의 항 상성은 곧 인체 전체의 항상성에 중대한 영향을 미치게 된다. 연 구에 의하면 노화가 진행되면서 피부 두께는 $20 \%$ 정도 감소하는데 (Orentreich \& Selmanowitz, 1969), 구조적으로도 노화된 피부는 세포수와 혈관이 감소되어 있다(Fenske \& Lober, 1986). 피부노화 의 주요 원인 중 하나는 콜라겐 생성의 변화와 조각난 엘라스틴이 증 가하는 것이다. 피부노화를 촉진하는 대표적인 예는 자외선으로 이 들은 콜라겐섬유의 정렬을 해체하고 비정상적인 엘라스틴 성분을 축 적함으로써 피부노화를 촉진한다(El-Domyati et al., 2002; Fisher et al., 1997).

피부는 콜라겐이나 엘라스틴과 같은 연결조직(connective tissue) 이 많은 비율을 차지한다. 콜라겐 섬유는 피부에 인장강도(tensile strength)을 가질 수 있도록 돕고 반면 엘라스틴은 탄성(elasticity) 과 복원력(resilence)을 가지게 한다(Farage et al., 2007). 콜라겐 은 인체의 가장 풍부한 단백질로서 피부의 지지와 강도를 가능하 게 한다. 콜라겐의 변화는 피부노화에서 중요한 과정으로 인식된다 (Baumann, 2007).

\section{2. 혈당, 최종당화산물 그리고 주름}

많은 연구들은 당뇨환자와 같이 장기간 동안 고혈당에 노출되면, 피부 섬유아세포의 노화가 되고, 콜라겐의 교차결합(cross-linking) 이 촉진된다고 보고한다(Blazer et al., 2002; Dekker et al., 2009; Paul \& Bailey, 1996). 고혈당은 피부의 주요 단백질인 콜라겐 매 트릭스에 부정적인 영향을 미친다. 특히 고혈당은 최종당화산물 (advanced glycation end product, AGE)의 형성을 증가시키고, 이
것은 다시 콜라겐과 엘라스틴의 교차결합의 수준을 높이게 된다 (Blazer et al., 2002; Dekker et al., 2009; Lan et al., 2009; Paul \& Bailey, 1996).

최종당화산물은 환원당(reducing sugars), 아스코빅산 (ascorbate), 그리고 다른 탄수화물들이 아미노산, 지질, 핵산과 비 효소적 반응을 함으로써 생성되는 이질적인 그룹의 분자들을 의미 한다(Fishman et al., 2018; Fu et al., 1996; Peppa et al., 2002; Vlassara \& Palace, 2002). 비록 이러한 과정은 노화와 함께 신체 내에서 지속적으로 일어나지만 특히 당뇨환자의 경우 최종당화산물 의 생성속도는 매우 빨라진다(Thorpe \& Baynes, 1996). AGE의 생 성에 영향을 미치는 인자들은 매우 다양하다. 예를 들어 흡연은 매 우 중요한 외생 기원중 하나이다(Nicholl \& Bucala, 1998). 최근의 연구에 의하면 식이, 특히 서구화된 식이는 AGE와 AGE 전구체들 의 생성에 상당히 많은 영향을 미치고 있었다(Peppa et al., 2002; Vlassara \& Palace, 2002). 안전, 보존, 맛과 향을 증진시키고, 모양 이 좋도록 만들기 위해 첨가되는 첨가물들이 당과 지질의 반응을 촉 진하여 다양한 불안정한 베타-디카보닐 유도체들을 만들어낸다(Lee et al., 1981; Pellegrino \& Cattaneo, 2001; Roldan et al., 2015). 외부에서 섭취된 $\mathrm{AGE}$ 의 $10 \%$ 정도가 위장관을 통해 흡수되며, 간 과 다른 조직으로 운반된다. 이중 3 분의 1 은 소변으로 배출되고, 나 머지는 당뇨와 같은 $\mathrm{AGE}$ 관련 질병과 관련된다. $\mathrm{AGE}$ 의 다양한 형태 로 인해서 특별한 AGE의 구조나 측정법은 아직 밝혀지지 않고 있다. $\mathrm{AGE}$ 의 일부는 대식세포나 다른 세포시스템의 세포내 함입을 통해 서 삼켜지고 보다 작은 분자량의 AGE 펩티드로 변환된다(Vlassara, 2001). 하지만 분해되지 못하는 $\mathrm{AGE}$ 들이 많이 있을 경우 다양한 질 환과 관련된다. 예를 들어 $\mathrm{AGE}$ 는 망막(Sheetz \& King, 2002)이 나 신장(Yamamoto et al., 2001), 말초신경(Graham \& Johnson, 1985; Sugimoto et al., 1997)이나 피부에 쌓여서 당뇨성 미세혈관 병증(microangiopathy)을 유발할 수 있다. AGE 콜라겐과 같은 중요 한 기질 단백질과 교차결합(cross-links)해서 결과적으로 매트릭스 단백질의 과잉 생산하게 하고, MMPs와 단백질 분해효소 억제제의 발현의 변화시킬 수 있다(Doi et al., 1992; Skolnik et al., 1991). 이것은 단백질 카이네이즈 $\mathrm{C}$ 의 활성화와 산화스트레스를 유발하 게 된다. 그리고 여러 가지 많은 연구들은 다양한 당화산물들이 당 뇨환자의 피부에 축적되어 물리화학적인 구조변화를 일으키고 이것 은 당뇨성 피부 관련 질환으로 이어진다고 보고한다(Beisswenger et al., 1995; Monnier et al., 1999; Peppa et al., 2003; Schleicher et al., 1997). 게다가 AGE는 당뇨성 상처의 회복속도를 지연시킨 다(Goova et al., 2001; Kochakian et al., 1996; Portero-Otin et al., 2002; Teixeira et al., 1999).

\section{3. 칼슘과 주름}

세포외기질 금속함유 단백분해효소(matrix metalloproteinases, $\mathrm{MMPs}$ )는 칼슘의존성 아연 펩티드 중간분해효소(calcium- 
dependent zinc endopeptidases)이다(Gomis-Rüth, 2009). MMP 는 모든 생명체에서 발견되며, 조직에서 거의 대부분의 세포외 기 질(extracellular matrix, $\mathrm{ECM}$ )을 분해할수 있고 리모델링한다. MMPs는 다양한 종류가 있어서 각각 특이적으로 콜라겐, 젤라스틴, 엘라스틴 등과 같이 $\mathrm{ECM}$ 의 특정 단백질을 담당한다 (Eisen et al, 1968; Gross \& Lapiere, 1962). 현재까지 25종의 MMPs가 발견되 었으며 이중에서 24가지는 인체에 존재한다(Puente et al., 2003). $\mathrm{MMPs}$ 의 단백질분해 능력은 혈관생성, 뼈의 발달, 상처치유, 자궁 과 유선의 발달과 같은 조직의 세포의 리모델링 뿐만 아니라, 세포의 증식, 이동, 부착과 같은 세포의 핵심적 과정에 영향을 미치게 된다 (Page-McCaw et al., 2007; Rowe \& Weiss, 2008). MMPs의 정상 범위를 넘어서 과잉활동은 다양한 병리적 현상으로 이어질 수 있다 (Hu et al., 2007). MMPs의 과잉조절은 암, 심혈관질환, 염증성질환 등에서 보고되고 있다(Gialeli et al., 2011; Itoh \& Nagase, 2002; Rundhaug, 2003). MMPs의 시간과 공간에 따른 적절한 조절은 세포주변과 세포외 환경의 항상성유지에 핵심요소가 된다(Löffek et al., 2011). MMPs의 발현과 활성은 유전자 전사(Yan \& Boyd, 2007), 전효소(Towle et al., 1998), 내재성 억제제(WojtowiczPraga et al., 1997) 등 다양한 요소에 의해 영향을 받게 된다. 종종 이들 과정에서 조절기능의 상실 또는 과잉조절은 다양한 병리적 상 태로 이어질 수 있다(Folgueras et al., 2004)

콜라겐, 엘라스틴과 같은 세포외 기질 단백질의 합성이 줄어들거 나 분해수준이 높아지면 피부의 구조가 변화하고 탄력이 감소하면서 피부노화가 촉진된다(Fisher et al., 2002; Kim et al., 2010). 연구 들에 의하면 광노화 등은 activating protein-1 (AP-1)을 활성화하 고, 활성화된 $\mathrm{AP}-1$ 은 다시 $\mathrm{MMP}-1$ 과 $\mathrm{MMP}-3$ 의 발현을 촉진하여 피부노화를 진행시킨다(Oh et al., 2006; Soter, 1990). Kim et al. (2013)의 연구에 의하면 인체의 진피 섬유아세포에 자외선을 조사 하였을 때 MMP-1과 MMP- 3 가 증가하고 있었다. MMP- 1 은 콜라 겐 type I과 III를 분해하는 collagenase 1으로 알려져 있다(Wang et al., 1999).

Elise 등의 연구에 의하면 칼슘수준은 MMPs활성에 영향을 미치 고 있었다. 연구진은 우선 칼슘의 세포내 유입을 차단하는 carboxy amido-triazole (CAI)를 처리하였다. CAI는 이미 수용체-작동성 비 전압통로(receptor-operated non-voltage gated)와 전압의존성 칼 슘통로 세포내 유입(voltage-gated calcium influx)을 차단한다고 보고되어 있었다((Felder et al., 1991; Kohn \& Liotta, 1990). 이 들의 실험결과 $\mathrm{CAI}$ 는 칼슘의 유입을 차단하였고 동시에 $\mathrm{MMP}-2$ 와 MMP-9의 발현이 억제되었다(Kohn et al., 1994).

\section{4. 혈액요소단백질}

혈액요소단백질(blood urea protein, BUN)은 단백질의 최종대 사산물로 인체 단백질의 영양학적 상태와 단백질 대사, 그리고 신장 의 상태를 반영한다. BUN은 작은 분자량으로 인해서 신장의 사구체
로 자유롭게 배출되지만 세뇨관(tubule)을 통해 재흡수되어 사구체 의 수분 균형(glomerular water balance)에서 생리학적으로 중요한 역할을 한다. 많은 연구들은 정상상태를 벗어난 높은 수치의 BUN은 인체의 다양한 질병과 관련이 있다고 보고하였다.

세포실험에 의하면 요소(urea)가 포함된 배지에서 배양된 지방 세포는 인슐린 민감성(insulin sensitivity)가 감소하였다(D'Apolito et al., 2010). 마우스를 이용한 동물실험에 의하면 요소 수치가 높 은 마우스는 인슐린 저항성과 포도당 내성을 보인다. 그리고 정상 마우스에 요소를 주입하였을 때 이와 동일한 수준의 인슐린 저항성 을 보인다(D'Apolito et al., 2010). Xie et al. (2018)의 연구에 의 하면 BUN $25 \mathrm{mg} / \mathrm{dl}$ 를 기준으로 2개 그룹으로 나누었을 때, 하위그 룹에 비해 상위그룹의 당뇨 위험이 1.18 배 증가한다. D'Apolito et al. (2010)은 체내의 요소가 활성산소의 생산을 증가시킨다고 보고 하였으며 이것은 췌장세포의 손상, 인슐린 저항성 증가, 당내성 증 가 등과 관련이 있다. Koppe et al. (2016)과 Thomas et al. (2015) 의 연구에 의하면 만성적인 신장질환자에서 나타나는 인슐린 분비 의 손상은 순환계에서 상승한 요소수치에 의한 것일 수 있다. 그리 고 만성 신장질환자들은 인슐린 반감기가 증가한다(Rubenstein \& Spitz, 1968). 높은 BUN수치는 당뇨발생의 위험성을 증가시킨다. 관상동맥질환(coronary artery disease)의 위험은 연령, 신장질환, 혈압, 염증성 물질 등 다양한 인자들과 관련이 있다(Allman et al., 2002; Anavekar et al., 2004). 최근 BUN이 심혈관질환의 중요한 원인중 하나로 떠오르고 있다. 몇몇 연구들은 병원 입원시 높은 수 치의 BUN을 가진 경우 급성 심장손상의 위험이 높다고 보고하였다 (Aronson et al., 2004; Fonarow et al., 2005). 뿐만 아니라 BUN 은 심혈관질환이 없는 환자에게도 위험한 질병 수준을 알리는 중요 한 지표로 나타나고 있다(Pan et al., 2013; Seleno, 2011). BUN은 혈관의 동역학적 손상을 반영할뿐만 아니라 레닌-안지오텐신-알두 스테론 시스템과 같은 신경내분비계의 활성수준(Schrier, 2008)과 교감신경계의 상태를 알려준다(Kazory, 2010).

\section{Chloride ion과 혈당조절}

췌장 베타세포의 기능에서 막의 음이온채널과 음이온에 대한 연 구는 아직 양적으로 질적으로 제한되어 있다(Best et al., 1996). 연 구보고들에 의하면 췌장의 샘(islets)들은 포도당 민감성 음이온 흐름 (glucose-sensitive anion fluxes)를 가지고 있으며 음이온은 인슐린 분비를 실질적으로 유의미하게 조절한다(Lindström et al., 1986; Sehlin, 1978). 뿐만 아니라 음이온 채널 차단제들(anion channel blockers)은 포도당-의존성 췌장샘(islets)들의 전기적 활성을 강력 하게 조절한다(Pace \& Tarvin, 1983). Kinard \& Satin (1995)과 Allman et al. (2002)은 췌장의 베타세포들에서 새로운 음이온 선 택적 채널을 발견하고 음이온 투과성 이온채널에 의해 매개되어 췌 장의 기능이 영향을 받는다고 보고하였다. 이들 췌장의 베타세포에 있는 염소 음이온 선택적 채널(anion-permeable pancreatic islet 


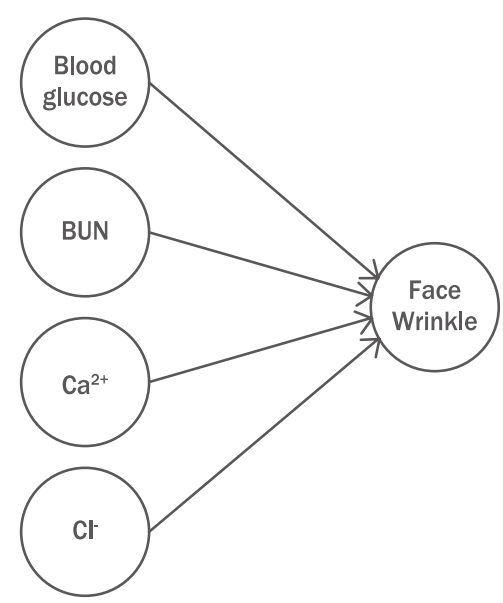

Figure 1. Study model.

beta-cell $\mathrm{Cl}^{-}$channel)은 저장액 상태(Drews et al., 1998)에서 세 포가 팽창될 때나 세포내 cAMP의 상승, 포도당 자체(Best et al., 1997)에 의해서 활성화된다(Eddlestone et al., 1985). 활성화된 염 소 음이온채널은 세포밖으로 음이온을 방출하고, 이와 함께 물이 방 출되어 세포부피를 감소시킨다. 세포내부가 음전하로 변화하면서, 이어서 전압의존성 칼슘채널이 열려 칼슘 세포내부로 유입된다. 그 런 다음 칼슘양이온 의존성 인슐린 방출 $\left(\mathrm{Ca}^{2+}-\right.$ dependent insulin secreation)이 이루어진다.

\section{Methods}

\section{1. 연구대상자}

본 연구의 대상자는 인터넷 등을 통하여 모집하였으며 실험 전에 연구윤리위원회의 승인(IRB No. Dbirb-19001)을 받고, 실험과 관 련된 내용을 참가자에게 설명한 후 동의서를 서면으로 받았다. 참 가자 중 질병이 있거나 약물섭취자, 홍삼이나 건강식품을 실험 전 2 주 이내에 섭취하였던 자는 모두 제외하였다. 총 실험 참가자는 모두 77 명이었으며 데이터 결과에서 평균보다 2 표준편차를 벗어난 이상 치는 제외하였고, 최종적으로 64 명의 여성을 대상으로 분석을 하였 다. 본 연구 대상자들의 연령은 평균 $44 \pm 6$ 세 였다.

\section{2. 연구가설과 모형}

본 연구의 가설은 Figure 1에서 제시한 것처럼 다음의 4 가지였다. 첫째, 혈당수준은 얼굴 주름의 수준에 영향을 미칠 것이다. 둘째, 혈 액 내 요소 단백질인 BUN은 얼굴주름 수준에 영향을 미칠 것이다. 셋째, 혈액 칼슘농도는 얼굴주름에 영향을 미칠 것이다. 넷째, 혈액 염화이온은 얼굴 주름에 영향을 미칠 것이다.

\section{3. 측정방법}

본 연구에서 혈액지표인 혈당 $\mathrm{BUN}, \mathrm{Ca}^{2+}, \mathrm{Cl}^{-}$은 아침 10 시에 녹 십자사(Green Cross Corp., Seoul)에서 실험장소(서울시 금천구) 를 방문하여 혈액을 채취하였다. 참가자는 전날 오후 7시 이후로 물 을 제외하고 일체의 음식과 음료를 섭취하지 않도록 하였다. 피부 주 름 측정은 봄텍(BOMTECH)의 피부측정기(모델명 A-ONE Smart, Seoul)를 이용하여 측정하였다. 피부의 주름은 가장 낮은 수준이 0 이고 가장 높은 수치는 10 이다. 주름은 봄텍의 프로그램에서 사진의 명암비를 이용하여 주름의 크기와 깊이를 알고리즘에 의해 계산한 것이다.

\section{4. 통계적 분석방법}

본 연구에서 평균과 표준편차, 상관분석, 다중회귀분석은 모두 SPSS Ver.23.0을 이용하여 분석하였다. 분석 전에 측정변수들이 정 규분포가 되는지를 왜도와 첨도를 확인한 후 왜도 2.0 이하인 것을 확인한 후 분석을 진행하였다.

\section{Results}

1. 연구대상자의 일반적 특징(얼굴주름, 혈당, BUN, 칼슘, 염소이 온)의 평균과 표준편차

연구대상자의 일반적 특징 분석결과는 Table 1에 나타내었다. 분 석결과, 연구대상자의 주름의 평균은 $3.4 \pm 1.1$ 이었으며, 혈액 내 칼 슘농도는 $9.6 \pm 0.3 \mathrm{mg} / \mathrm{dL}$, 염소는 $96.6 \pm 3.0 \mathrm{mmol} / \mathrm{L}$, 혈액요소질 소(blood urea nitrogen, BUN)은 $9.7 \pm 3.2 \mathrm{mg} / \mathrm{dL}$ 였다.

\section{2. 주름과 혈당, BUN, 칼슘, 염소이온의 상관분석}

본 연구에서 주름, 칼슘, 염소, $\mathrm{BUN}$ 의 관계를 확인하기 위하여 상 관분석을 하였고 그 결과는 Table 2 에 나타내었다. 분석결과, 주름과 $\mathrm{BUN}$ 은 상관계수 0.399 , 유의확률 $p<0.001$ 로 통계적으로 유의하였

Table 1. The mean and standard deviation of the age and measurement variables of the study subjects

\begin{tabular}{lcccccc}
\hline & Age (year) & Wrinkle & Blood glucose & Calcium $(\mathrm{mg} / \mathrm{dL})$ & Chloride $(\mathrm{mmol} / \mathrm{L})$ & $\mathrm{BUN}(\mathrm{mg} / \mathrm{dL})$ \\
Mean & 44 & 3.4 & 91.0 & 9.6 & 96.6 & 9.7 \\
Standard deviation & 6 & 1.1 & 25.2 & 0.3 & 3.0 & 3.2 \\
\hline
\end{tabular}

BUN, blood urea nitrogen. 
다. 주름과 염소는 상관계수 $\mathrm{r}=-0.227$ 로 부(-)의 상관계수를 보였 으며 통계유의수준은 $p=0.051$ 로 $p<0.05$ 기준에 매우 근접한 주목할 만한 수치를 보였다. 주름과 칼슘의 경우에도 상관계수 $\mathrm{r}=0.217$, 유 의확률 $p=0.061$ 로 $p\langle 0.05$ 기준보다 높지만, 통계적으로 유의한 경향 성인 $p<0.01$ 보다 낮은 수치를 보이고 있었다. 칼슘과 요소 사이에는 상관계수 -0.357 , 유의확률 $p=0.001$ 로 통계적으로 유의한 수치를 보이고 있었다.

\section{3. 혈중 혈당, BUN, 칼슘, 염소이온의 얼굴 피부주름에 미치는 영향}

인체 혈액지표들 중에서 혈당, BUN, 칼슘, 염소, 의 영향을 다중 회귀분석으로 확인하였고, 그 결과는 Table 3 에 나타내었다. 분석결 과, 혈당의 비표준화계수는 0.019 , 유의확률 $p=0.027$ 로 통계적으로 유의한 양의 영향을 미치고 있었다. 이것은 혈당이 $1 \mathrm{mg} / \mathrm{dL}$ 만큼 증 가하면 주름이 0.019 만큼 증가한다는 의미이다. 혈당의 표준화계수 는 0.247 이었는데, 이것은 혈당이 1 표준편차 만큼 증가할 때 주름은 0.247 표준편차만큼 증가한다는 의미이다. BUN의 비표준화계수는 0.108 , 유의확률 $p=0.006$ 이었는데 이것은 BUN이 $1 \mathrm{mg} / \mathrm{dL}$ 만큼 증 가할 때 주름은 0.108 만큼 증가한다는 의미이다. 이외에 염소는 비 표준화계수가 -0.078 , 표준화계수가 -0.205 로 부(-)의 영향을 미 치고 있었으며 유의확률은 $\mathrm{p}=0.078$ 이였다. 독립변수의 종속변수에
대한 설명력인 $R^{2}$ 은 0.203 이었는데 이것은 독립변수들이 종속변수 인 주름살을 $20.3 \%$ 설명 또는 예측할 수 있다라는 의미이다.

\section{Discussion}

세계적인 고령화와 생활수준의 향상으로 현대인은 보다 외모에 관 심을 많이 가지게 되었다. 동서양을 막론하고 음식은 건강을 유지하 는데 중요한 요소로 인식되었다. 동양에서는 의식동원(醫食同源)이 라 하여 음식은 곧 약이 된다고 하였고, 서양의 히포크라테스는 음 식으로 고치지 못하는 병은 약으로도 고칠 수 없다고 하였다. 인도의 아유르베다에서 첫번째 약은 음식이다. 음식은 생리적 욕구뿐만 아 니라 심리적, 사회적 욕구에 관련되어 있으며 건강한 인체생리의 유 지에 균형된 영양섭취가 중요하다. 우리나라에서는 급속한 산업화와 도시화, 핵가족화가 진행되면서 과거의 전통적인 식생활이 서구화 되었다. 식자재에서도 외국에서 수입된 다양한 식품들이 중심이 되 었으며 특히 정제된 밀가루와 육류소비의 증가가 특징 중 하나가 된 다. 이로 인하여 영양과다로 인한 다양한 질병들이 증가하게 되었는 데 대사증후군으로 총칭되는 비만, 당뇨, 심혈관질환 등이 포함된다. 본 연구는 혈액내의 성분들 중 대표적인 영양소인 혈당, 칼슘, 염화

Table 2. Correlation between wrinkles and blood glucose, calcium ion, chlorine ion, and BUN

\begin{tabular}{|c|c|c|c|c|c|c|}
\hline & & Wrinkle & Blood glucose & BUN & Calcium ion & Chloride ion \\
\hline \multirow{2}{*}{ Wrinkle } & $r$ & 1 & & & & \\
\hline & $p$ & & & & & \\
\hline \multirow{2}{*}{ Blood glucose } & $r$ & $0.230^{*}$ & 1 & & & \\
\hline & $\mathrm{p}$ & 0.049 & & & & \\
\hline \multirow{2}{*}{ BUN } & $r$ & $0.399^{* *}$ & 0.189 & 1 & & \\
\hline & $\mathrm{p}$ & 0.000 & 0.095 & & & \\
\hline \multirow{2}{*}{ Calcium ion } & $r$ & 0.217 & 0.119 & 0.210 & 1 & \\
\hline & $\mathrm{p}$ & 0.061 & 0.296 & 0.061 & & \\
\hline \multirow{2}{*}{ Chloride ion } & $r$ & -0.227 & $0.223^{*}$ & -0.166 & $-0.357^{* *}$ & 1 \\
\hline & $\mathrm{p}$ & 0.051 & 0.049 & 0.141 & 0.001 & \\
\hline
\end{tabular}

${ }^{*} p<0.05 ;{ }^{* *} p<0.01$.

Table 3. Multiple regression analysis of the effects of calcium, chlorine, and BUN on wrinkles

\begin{tabular}{|c|c|c|c|c|c|}
\hline & \multicolumn{2}{|c|}{ Non-standardized coefficient } & \multirow{2}{*}{$\begin{array}{c}\begin{array}{c}\text { Standardized } \\
\text { coefficient }\end{array} \\
\text { beta }\end{array}$} & \multirow{2}{*}{$t$} & \multirow{2}{*}{ Significance level } \\
\hline & B & Standard error & & & \\
\hline Intercept & 6.016 & 6.754 & & 0.891 & 0.376 \\
\hline BUN & 0.108 & 0.038 & 0.310 & 2.832 & 0.006 \\
\hline Chloride & -0.078 & 0.043 & -0.205 & -1.789 & 0.078 \\
\hline Calcium ion & 0.256 & 0.455 & 0.063 & 0.563 & 0.575 \\
\hline Blood glucose & 0.019 & 0.008 & 0.247 & 2.257 & 0.027 \\
\hline
\end{tabular}

BUN, blood urea nitrogen. 
이온, 그리고 단백질의 최종 대사산물인 혈액 요소단백질인 BUN이 피부 주름에 미치는 영향을 실증적인 통계분석으로 확인한 것이다. 지금까지 대사증후군과 피부노화의 관계에 대한 연구는 다소 있었으 나, 대사증후군의 중요한 표지자들이 피부노화에 직접적인 영향을 미친다는 보고는 아직 없었다. 본 연구에 의하면 BUN이 1 만큼 증가 하면 피부주름은 0.108 만큼 증가한다. 그리고 혈당이 1 만큼 증가하 면 주름은 0.019 만큼 증가한다. 반면 본 논문에 포함되어 있지는 않 았지만 지질은 피부주름에 통계적으로 유의한 영향을 미치지 않고 있었다.

Nagase et al. (2013)은 동물모델을 통해 피부노화가 대사증후군 과 관련이 있음을 보고하였다. 대사증후군이 있을 때에 피부에 미네 랄코르티코이드 수용체의 발현이 증가하고 염증성 표지가 증가하며, 산화스트레스가 증가하는 것을 확인하였다. 이것은 대사증후군에서 증가한 활성산소는 유전자와 미토콘드리아 기능, 인슐린 저항성을 포함하는 호르몬교란 등을 일으켜 최종적으로 피부노화로 이어질 수 있다는 것이다(Zouboulis \& Makrantonaki, 2011). 그리고 대사증 후군에서 흔히 높게 나타나는 당화산물(glycation product)는 콜라겐 과 교차연결 되어 피부 콜라겐의 기능을 손상시킴으로써 피부의 노 화와 주름을 만들 수 있다. 실제로 콜라겐의 당화현상은 피부노화의 병인생성과정에서 중요한 요소로 다루어지고 있다(Lubrano et al., 2015; Rinnerthaler et al., 2015). 즉, 본 연구에서는 BUN과 혈당 이 피부주름에 통계적으로 유의한 정(+)의 영향을 미치고 있었는데, 이것은 BUN의 활성산소 증가는 인슐린 민감성을 낮추어 혈당상승 을 유발하고, 높아진 혈당은 피부 콜라겐과 당화과정을 거쳐서 피부 주름을 포함한 노화를 촉진하는 것으로 추정된다.

\section{Conclusion}

본 연구에 의하면 피부의 얼굴 주름은 혈당과 BUN에 의해 통계 적으로 유의한 정 $(+)$ 의 영향을 받고 있었다. 비록 유의수준 $p<0.05$ 에는 다소 미치지 못하는 유의확률 $p=0.078$ 였지만 염화이온은 얼굴 주름에 부(-)의 영향을 미치고 있었다. 이상의 결과는 최종당화산물 의 수준이 얼굴주름에 매우 중요한 요소가 될 수 있음을 암시한다. 향후 이와 관련된 보다 진전된 연구가 필요할 것으로 사료된다. 본 연구는 평균나이 44 세의 여성을 대상으로 하였다는 한계를 갖는다. 향후 남성과 보다 다양한 연령대를 대상으로 한 비교연구가 가능할 것이다.

\section{Author's contribution}

MJK pre-structured research design and title of the paper, review the setting of a research question, and participated in analyzing the components of the entire paper. HSN collected data, prepared and analyzed the questionnaire, organized prior research, described the research question, and participated in analyzing the questionnaire.

\section{Author details}

Hyun Sun Noh (Graduate student), Department of Beauty and Arts, Dongbang Culture University, 60, Seongbukro, 28 road, Seongbuk-gu, Seoul 02838, Korea; Moon Ju Kim (Professor), Department of Beauty and Arts, Dongbang Culture University, 60, Seongbuk-ro, 28 road, Seongbukgu, Seoul 02838, Korea.

\section{References}

Allman KC, Shaw U, Hachamovitch R, Udelson JE. Myocardial viability testing and impact of revascularization on prognosis in patients with coronary artery disease and left ventricular dysfunction: a meta-analysis. Journal of the American College of Cardiology, 39: 1151-1158, 2002.

Anavekar NS, McMurray JJ, Velazquez EJ, Solomon SD, Kober L, Rouleau JL, White HD, Nordlander R, Maggioni A, Dickstein $\mathrm{K}$, et al. Relation between renal dysfunction and cardiovascular outcomes after myocardial infarction. New England Journal of Medicine, 351: 1285-1295, 2004.

Aronson D, Mittleman MA, Burger AJ. Elevated blood urea nitrogen level as a predictor of mortality in patients admitted for decompensated heart failure. The American Journal of Medicine, 116: 466-473, 2004.

Baumann L. Skin ageing and its treatment. The Journal of Pathology, 211: 241-251, 2007.

Beisswenger PJ, Makita Z, Curphey TJ, Moore LL, Jean S, Brinck-Johnsen T, Bucala R, Vlassara H. Formation of immunochemical advanced glycosylation end products precedes and correlates with early manifestations of renal and retinal disease in diabetes. Diabetes, 44: 824829, 1995.

Best L, Brown PD, Tomlinson S. Mini review articleanion fluxes, volume regulation and electrical activity in the mammalian pancreatic $\beta$-cell. Experimental Physiology, 82: 957-966, 1997. 
Best L, Sheader EA, Brown PD. A volume-activated anion conductance in insulin-secreting cells. Pflügers Archiv, 431: 363-370, 1996.

Blazer S, Khankin E, Segev Y, Ofir R, Yalon-Hacohen M, KraOz Z, Gottfried Y, Larisch S, Skorecki KL. High glucoseinduced replicative senescence: point of no return and effect of telomerase. Biochemical and Biophysical Research Communications, 296: 93-101, 2002.

Christensen K, Thinggaard M, McGue M, Rexbye H, Aviv A, Gunn D, van der Ouderaa F, Vaupel JW. Perceived age as clinically useful biomarker of ageing: cohort study. British Medical Journal, 339: b5262, 2009.

D’Apolito M, Du X, Zong H, Catucci A, Maiuri L, Trivisano T, Pettoello-Mantovani M, Campanozzi A, Raia V, Pessin $\mathrm{JE}$, et al. Urea-induced ROS generation causes insulin resistance in mice with chronic renal failure. The Journal of Clinical Investigation, 120: 203-213, 2010.

Dekker P, Maier AB, Van Heemst D, De Koning-Treurniet C, Blom J, Dirks RW, Tanke HJ,Westendorp RG. Stressinduced responses of human skin fibroblasts in vitro reflect human longevity. Aging Cell, 8: 595-603, 2009.

Doi T, Vlassara H, Kirstein M, Yamada Y, Striker GE, Striker LJ. Receptor-specific increase in extracellular matrix production in mouse mesangial cells by advanced glycosylation end products is mediated via plateletderived growth factor. Proceedings of the National Academy of Sciences of the United States of America, 89: 2873-2877, 1992.

Draelos Z, Draelos ZK, Pugliese PT. Physiology of the skin (third edition). Allured Publishing Corporation, IL, USA, pp121-185, 2011.

Drews G, Zempel G, Krippeit-Drews P, Britsch S, Busch GL, Kaba NK, Lang F. lon channels involved in insulin release are activated by osmotic swelling of pancreatic B-cells. Biochimica et Biophysica Acta (BBA)-Biomembranes, 1370: 8-16, 1998.

Eddlestone GT, Oldham SB, Lipson LG, Premdas FH, Beigelman PM. Electrical activity, cAMP concentration, and insulin release in mouse islets of Langerhans. American Journal of Physiology, 248: C145-C153, 1985.

Eisen AZ, Jeffrey JJ, Gross J. Human skin collagenase. Isolation and mechanism of attack on the collagen molecule. Biochimca et Biophysica acta, 151: 637-645, 1968.
El-Domyati M, Attia S, Saleh F, Brown D, Birk DE, Gasparro $\mathrm{F}$, Ahmad H, Uitto J. Intrinsic aging vs. photoaging: a comparative histopathological, immunohistochemical, and ultrastructural study of skin. Experimental Dermatology, 11: 398-405, 2002.

Farage MA, Miller KW, Elsner P, Maibach HI. Structural characteristics of the aging skin: a review. Cutaneous and Ocullar Toxicology, 26: 343-357, 2007.

Felder CC, Ma AL, Liotta LA, Kohn EC. The antiproliferative and antimetastatic compound L651582 inhibits muscarinic acetylcholine receptor-stimulated calcium influx and arachidonic acid release. The Journal of Pharmacology and Experimental Therapeutics, 257: 967-971, 1991.

Fenske NA, Lober CW. Structural and functional changes of normal aging skin. Journal of the American Academy of Dermatology, 15: 571-585, 1986.

Fisher GJ, Kang S, Varani J, Bata-Csorgo Z, Wan Y, Datta $\mathrm{S}$, Voorhees JJ. Mechanisms of photoaging and chronological skin aging. Archives of Dermatology, 138: 1462-1470, 2002.

Fisher GJ, Wang ZQ, Datta SC, Varani J, Kang S, Voorhees, $\mathrm{JJ}$. Pathophysiology of premature skin aging induced by ultraviolet light. The New England Journal of Medicine, 337: 1419-1428, 1997.

Fishman SL, Sonmez H, Basman C, Singh V, Poretsky L. The role of advanced glycation end-products in the development of coronary artery disease in patients with and without diabetes mellitus: a review. Molecular Medicine, 24: 59, 2018.

Folgueras AR, Pendás AM, Sánchez LM, López-Otín C. Matrix metalloproteinases in cancer: from new functions to improved inhibition strategies. The International Journal of Developmental Biology, 48: 411-424, 2004.

Fonarow GC, Adams KF, Abraham WT, Yancy CW, Boscardin WJ. Risk stratification for in-hospital mortality in acutely decompensated heart failure: classification and regression tree analysis. The Journal of American Medical Association, 293: 572-580, 2005.

Fu MX, Requena JR, Jenkins AJ, Lyons TJ, Baynes JW, Thorpe SR. The advanced glycation end product, Nepsilon(carboxymethyl)lysine, is a product of both lipid peroxidation and glycoxidation reactions. The Journal of Biological Chemistry, 271: 9982-9986, 1996. 
Gialeli C, Theocharis AD, Karamanos NK. Roles of matrix metalloproteinases in cancer progression and their pharmacological targeting. The FEBS Journal, 278: 1627, 2011.

Gomis-Rüth FX. Catalytic domain architecture of metzincin metalloproteases. The Journal of Biologycal Chemistry, 284: 15353-15357, 2009.

Goova MT, Li J, Kislinger T, Qu W, Lu Y, Bucciarelli LG, Nowygrod S, Wolf BM, Caliste X, Yan SF, Stem DM, Schmidt AM. Blockade of receptor for advanced glycation end-products restores effective wound healing in diabetic mice. The American Journal of Pathology, 159: 513-525, 2001.

Graham AR, Johnson PC. Direct immunofluorescence findings in peripheral nerve from patients with diabetic neuropathy. Annals of Neurology, 17: 450-454, 1985.

Gross J, Lapiere CM. Collagenolytic activity in amphibian tissues: a tissue culture assay. Proceedings of the National Academy of Sciences of the United States of America, 48: 1014-1022, 1962.

Gunn DA, Rexbye H, Griffiths CE, Murray PG, Fereday A, Catt $\mathrm{SD}$, Tomlin CC, Strongitharm BH, Perrett DI, Catt M, et al. Why some women look young for their age. PloS One, 4: e8021, 2009.

Hu J, Van den Steen PE, Sang QX, Opdenakker G. Matrix metalloproteinase inhibitors as therapy for inflammatory and vascular diseases. Nature Reviews Drug Discovery, 6: 480-498, 2007.

Itoh Y, Nagase H. Matrix metalloproteinases in cancer. Essays in Biochemistry, 38: 21-36, 2002.

Kazory A. Emergence of blood urea nitrogen as a biomarker of neurohormonal activation in heart failure. The American Journal of Cardiology, 106: 694-700, 2010.

Kim DS, Jeon BK, Lim NY, Mun YJ, Lee YE, Woo WH. Ethanol extract of Dioscorea batatas stimulates procollagen production and reduces UVB-induced MMPs activity in skin. Journal of Physiology \& Pathology in Korean Medicine, 27: 183-188, 2013.

Kim EJ, Kim MK, Jin XJ, Oh JH, Kim JE, Chung JH. Skin aging and photoaging alter fatty acids composition, including 11, 14, 17-eicosatrienoic acid, in the epidermis of human skin. Journal of Korean Medical Science, 25: 980-983, 2010

Kinard TA, Satin LS. An ATP-sensitive Cl-channel current that is activated by cell swelling, cAMP, and glyburide in insulin-secreting cells. Diabetes, 44: 1461-1466, 1995.

Kochakian M, Manjula BN, Egan JJ. Chronic dosing with aminoguanidine and novel advanced glycosylation end product-formation inhibitors ameliorates cross-linking of tail tendon collagen in STZ-induced diabetic rats. Diabetes, 45: 1694-1700, 1996.

Kohn EC, Jacobs W, Kim YS, Alessandro R, Stetler-Stevenson WG, Liotta LA. Calcium influx modulates expression of matrix metalloproteinase-2 (72-kDa type IV collagenase, gelatinase A). Journal of Biological Chemistry, 269: 21505-21511, 1994.

Kohn EC, Liotta LA. L651582: a novel antiproliferative and antimetastasis agent. Journal of the National Cancer Institute, 82: 54-60, 1990.

Koppe L, Nyam E, Vivot K, Manning Fox JEM, Dai XQ, Nguyen BN, Trudel D, Attané C, Moullé VS, MacDonald PE, et al. Urea impairs $\beta$ cell glycolysis and insulin secretion in chronic kidney disease. The Journal of Clinical Investigation, 126: 3598-3612, 2016.

Löffek S, Schilling O, Franzke CW. Biological role of matrix metalloproteinases: a critical balance. European Respiratory Journal, 38: 191-208, 2011.

Lan CC, Wu CS, Kuo HY, Huang SM, Chen GS. Hyperglycaemic conditions hamper keratinocyte locomotion via sequential inhibition of distinct pathways: new insights on poor wound closure in patients with diabetes. British Journal of Dermatology, 160: 1206-1214, 2009.

Lee TC, Kimiagar M, Pintauro SJ, Chichester CO. Physiological and safety aspects of Maillard browning of foods. Progress in Food and Nutrition Sciences, 5: 243-256, 1981.

Lindström P, Norlund L, Sehlin J. Potassium and chloride fluxes are involved in volume regulation in mouse pancreatic islet cells. Acta Physiologica Scandinavica, 128: 541-546, 1986.

Lubrano C, Valacchi G, Specchia P, Gnessi L, Rubanenko EP, Shuginina EA, Trukhanov AI, Korkina LG, De Luca C. Integrated haematological profiles of redox status, lipid, and inflammatory protein biomarkers in benign obesity and unhealthy obesity with metabolic syndrome. Oxidative Medicine and Cellular Longevity, 2015: 490613, 2015.

Monnier VM, Bautista O, Kenny D, Sell DR, Fogarty J, Dahms 
W, Cleary PA, Lachin J, Genuth S. Skin collagen glycation, glycoxidation, and crosslinking are lower in subjects with long-term intensive versus conventional therapy of type 1 diabetes: relevance of glycated collagen products versus $\mathrm{HbA1c}$ as markers of diabetic complications. DCCT skin collagen ancillary study group. diabetes control and complications trial. Diabetes, 48: 870-880, 1999.

Morganti P, Chen HD, Gao, HH, Li Y, Jacobson C, Arct J, Fabianowski W. Nanoscience challenging cosmetics, healthy food \& biotextiles. SÖFW-Journal, 135: 32-40, 2009.

Nagase T, Akase T, Sanada H, Minematsu T, Ibuki A, Huang L, Asada M, Yoshimura K, Nagase M, Shimada T, et al. Aging-like skin changes in metabolic syndrome model mice are mediated by mineralocorticoid receptor signaling. Aging Cell, 12: 50-57, 2013.

Nicholl ID, Bucala R. Advanced glycation endproducts and cigarette smoking. Cellular and Molecular Biology, 44: 1025-1033, 1998.

Nkengne A, Bertin C, Stamatas GN, Giron A, Rossi AB, Issachar N, Fertil B. Influence of facial skin attributes on the perceived age of Caucasian women. Journal of the European Academy of Dermatology and Venereology, 22: 982-991, 2008.

Oh JH, Kim A, Park JM, Kim SH, Chung AS. Ultraviolet B-induced matrix metalloproteinase-1 and-3 secretions are mediated via PTEN/Akt pathway in human dermal fibroblasts. Journal of Cellular Physiology, 209: 775-785, 2006.

Orentreich N, Selmanowitz VJ. Section of Biological and medical sciences: level of biological funcions with aging. Transactions of the New York Academy of Sciences, 31: 992-1012, 1969.

Pace CS, Tarvin JT. pH modulation of glucose-induced electrical activity in B-cells: involvement of $\mathrm{Na} / \mathrm{H}$ and $\mathrm{HCO}_{3} / \mathrm{Cl}$ antiporters. The Journal of Membrane Biology, 73: 39-49, 1983.

Page-McCaw A, Ewald AJ, Werb Z. Matrix metalloproteinases and the regulation of tissue remodelling. Nature Reviews Molecular Cell Biology, 8: 221-233, 2007.

Pan SW, Kao HK, Yu WK, Lien TC, Chen YW, Wang JH, Kou YR. Synergistic impact of low serum albumin on intensive care unit admission and high blood urea nitrogen during intensive care unit stay on post-intensive care unit mortality in critically ill elderly patients requiring mechanical ventilation. Geriatrics and Gerontology International, 13: 107-115, 2013.

Paul RG, Bailey AJ. Glycation of collagen: the basis of its central role in the late complications of ageing and diabetes. The International Journal of Biochemistry and Cell Biology, 28: 1297-1310, 1996.

Pellegrino L, Cattaneo S. Occurrence of galactosyl isomaltol and galactosyl beta-pyranone in commercial drinking milk. Die Nahrung, 45: 195-200, 2001.

Peppa M, Brem H, Ehrlich P, Zhang JG, Cai W, Li Z, Croitoru A, Thung S, Vlassara H. Adverse effects of dietary glycotoxins on wound healing in genetically diabetic mice. Diabetes, 52: 2805-2813, 2003.

Peppa M, Uribarri J, Vlassara, H. Advanced glycoxidation. A new risk factor for cardiovascular disease? Cardiovascular Toxicology, 2: 275-287, 2002.

Portero-Otin M, Pamplona R, Bellmunt MJ, Ruiz MC, Prat J, Salvayre R, Nègre-Salvayre A. Advanced glycation end product precursors impair epidermal growth factor receptor signaling. Diabetes, 51: 1535-1542, 2002.

Puente XS, Sánchez LM, Overall CM, López-Otin C. Human and mouse proteases: a comparative genomic approach. Nature Reviews. Genetics, 4: 544-558, 2003.

Rexbye H, Petersen I, Johansens M, Klitkou L, Jeune B, Christensen K. Influence of environmental factors on facial ageing. Age and Ageing, 35: 110-115, 2006.

Rinnerthaler M, Bischof J, Streubel MK, Trost A, Richter K. Oxidative stress in aging human skin. Biomolecules, 5: 545-589, 2015.

Roldan M, Loebner J, Degen J, Henle T, Antequera T, RuizCarrascal J. Advanced glycation end products, physicochemical and sensory characteristics of cooked lamb loins affected by cooking method and addition of flavour precursors. Food Chemistry, 168: 487-495, 2015.

Rowe RG, Weiss SJ. Breaching the basement membrane: who, when and how? Trends in Cell Biology, 18: 560574, 2008.

Rubenstein $\mathrm{AH}$, Spitz I. Role of the kidney in insulin metabolism and excretion. Diabetes, 17: 161-169, 1968.

Rundhaug JE. Matrix metalloproteinases, angiogenesis, and cancer: reduction of wound angiogenesis in patients treated with BMS-275291, a broad spectrum matrix metalloproteinase inhibitor. Clinical Cancer Research, 9: 
551-554, 2003.

Schleicher ED, Wagner E, Nerlich AG. Increased accumulation of the glycoxidation product $\mathrm{N}$ (epsilon)-(carboxymethyl) lysine in human tissues in diabetes and aging. The Journal of Clinical Investigation, 99: 457-468, 1997.

Schrier RW. Blood urea nitrogen and serum creatinine: not married in heart failure. Circulation: Heart Failure, 1: 2-5, 2008.

Sehlin J. Interrelationship between chloride fluxes in pancreatic islets and insulin release. American Journal of Physiology, 235: E501-E508, 1978.

Seleno N. Elevation of blood urea nitrogen is Predictive of Long-term Mortality in Critically III Patients Independent of "Normal" Creatinine: Beier K, Eppanapally S, Bazick H, et al. Crit Care Med 2011; 39: 305-13. Journal of Emergency Medicine, 40: 724, 2011.

Sheetz MJ, King GL. Molecular understanding of hyperglycemia's adverse effects for diabetic complications. Journal of American Medical Association, 288: 25792588, 2002.

Skolnik EY, Yang Z, Makita Z, Radoff S, Kirstein M, Vlassara $\mathrm{H}$. Human and rat mesangial cell receptors for glucosemodified proteins: potential role in kidney tissue remodelling and diabetic nephropathy. Journal of Experimental Medicine, 174: 931-939, 1991.

Soter NA. Acute effects of ultraviolet radiation on the skin. Seminars in Dermatology, 9: 11-15, 1990.

Sugimoto K, Nishizawa Y, Horiuchi S, Yagihashi S. Localization in human diabetic peripheral nerve of $\mathrm{N}$ (epsilon)carboxymethyllysine-protein adducts, an advanced glycation endproduct. Diabetologia, 40: 1380-1387, 1997.

Tabor A, Blair RM. Nutritional cosmetics: beauty from within. William Andrew, New York, p1:16-22, 2009.

Teixeira AS, Caliari MV, Rocha OA, Machado RD, Andrade SP. Aminoguanidine prevents impaired healing and deficient angiogenesis in diabetic rats. Inflammation, 23: 569581, 1999.

Thomas SS, Zhang L, Mitch WE. Molecular mechanisms of insulin resistance in chronic kidney disease. Kidney
International, 88: 1233-1239, 2015.

Thorpe SR, Baynes JW. Role of the maillard reaction in diabetes mellitus and diseases of aging. Drugs and Aging, 9: 69-77, 1996.

Tobin DJ. Biochemistry of human skin: our brain on the outside. Chemical Society Reviews, 35: 52-67, 2006.

Towle CA, Wright M, Hecht AC, Kuong SJ, Papanicolas LE, Totkovic R, Mankin HJ, Treadwell BV. A matrix metalloproteinase proenzyme activator produced by articular cartilage. Biochemical and Biophysical Research Communications, 247: 324-331, 1998.

Vlassara $\mathrm{H}$. The AGE-receptor in the pathogenesis of diabetic complications. Diabetes/Metabolism Research and Reviews, 17: 436-443, 2001.

Vlassara H, Palace MR. Diabetes and advanced glycation endproducts. Journal of Internal Medicine, 251: 87-101, 2002.

Wang Y, Johnson AR, Ye QZ, Dyer RD. Catalytic activities and substrate specificity of the human membrane type 4 matrix metalloproteinase catalytic domain. The Journal of Biological Chemistry, 274: 33043-33049, 1999.

Wojtowicz-Praga SM, Dickson RB, Hawkins MJ. Matrix metalloproteinase inhibitors. Investigational New Drugs, 15: 61-75, 1997.

Xie Y, Bowe B, Li T, Xian H, Yan Y, Al-Aly Z. Higher blood urea nitrogen is associated with increased risk of incident diabetes mellitus. Kidney International, 93: 741-752, 2018.

Yamamoto Y, Kato I, Doi T, Yonekura H, Ohashi S, Takeuchi M, Watanabe T, Yamagishi SI, Sakurai S, Takasawa $\mathrm{S}$, Okamoto H, Yamamoto H.. Development and prevention of advanced diabetic nephropathy in RAGEoverexpressing mice. The Journal of Clinical Investigation, 108: 261-268, 2001.

Yan C, Boyd DD. Regulation of matrix metalloproteinase gene expression. Journal of Cellular Physiology, 211: 19-26, 2007.

Zouboulis CC, Makrantonaki E. Clinical aspects and molecular diagnostics of skin aging. Clinics in Dermatology, 29: 3-14, 2011. 


\section{국문초록}

\section{혈당, 칼슘, 염화이온, 혈액요소질소가 피부주름에 미치는 영향}

노현선, 김문주

동방문화대학원대학교 뷰티예술학과, 서울, 한국

목적: 본 연구는 혈액내의 혈당, 요소질소(BUN), 칼슘, 염화이온이 폐경기 전 여성의 얼굴 주름살에 미치는 영향을 통계적으로 확 인하고자 하였다. 방법: 이 연구는 동방대학교 연구윤리위원의 심사를 받았으며, 참가자는 인터넷을 통하여 모집하였다. 모집대상 은 폐경기 전 여성으로 한정하였으며 질병에 걸려있거나 약물, 건강식품을 섭취하는 자는 제외하였다. 혈액채취는 녹십자사(Green Cross Corp., Seoul)에서 간호사가 진행하였으며 혈액성분도 녹십자사에서 분석하였다. 얼굴의 주름수준은 봄텍(BOMTECH, Seoul)의 피부측정기(모델명 A-ONE Smart)로 측정하였다. 모집인원은 총 77 명이었으나 혈액 측정변수가 이상치를 벗어난 13 명 을 제외하고 나머지 64명(평균연령 을 대상으로 통계분석(SPSS Ver.23.0)을 하였다. 결과: 분석결과 혈당의 비표준화계수는 0.019, 유의확률 $\mathrm{p}=0.027$ 로 통계적으로 유의한 양의 영향을 미치고 있었다. BUN의 비표준화계수는 0.108 , 유의확률 $p=0.006$ 이었는데 이것은 BUN이 $1 \mathrm{mg} / \mathrm{dL}$ 만큼 증가할 때 주름은 0.108 만큼 증가한다는 의미이다. 독립변수의 종속변수에 대한 설명력인 $\mathrm{R}^{2}$ 은 0.203 이었다. 결론: 본 연구에 의하면 심혈관질환, 당뇨 등에 영향을 미치는 인자로 알려진 혈당과 BUN이 얼굴 주름살에 영향을 미치고 있었다. 본 연구는 폐경기 전 여성 64 명을 대상으로 하였기에 전체 연령으로 일반화할 수 없다라는 한계를 갖는다. 향후 폐경기 이 후 여성과 남성을 포함한 보다 넓은 연구 대상자들을 통하여 비교연구가 필요할 것으로 사료된다.

핵심어: 혈당, 혈중요소질소, 칼슘이온, 염화이온, 주름살

\section{참고문헌}

김대성, 전병국, 임난영, 문연자, 이영은, 우원홍. 마 에탄올추출물의 피부 collagen 합성 촉진 및 MMPs 활성 억제효과. 동의생리병리학회지, $27: 183-188,2013$. 


\section{中文摘要}

\section{血糖、钙、氯离子和血尿素氮对皮肤皱纹的影响分析}

\section{魯泫瑄, 金紋主}

东方文化大学院大学校美容艺术学科, 首尔, 韩国

目的: 本研究的目的是统计学验证血糖, 血尿素氮（BUN）, 钻和氯离子对绝经前妇女面部皱纹的影响。方 法: 通过互联网招募绝经前妇女作为研究对象。那些患有疾病或食用人参等药物或保健食品的人被排除在外。 获得了血糖，BUN，钻和氯离子的水平，并使用皮肤仪测量了面部皱纹。进行了多元回归分析，以评估血糖， BUN, 钻和氯离子对面部皱纹的影响。结果：在排除血液测量变量偏离异常值的 13 个之之后, 对其余64位参 与者进行了统计分析。分析显示血糖的非标准化系数为 0.019 , 显着概率为 $p=0.027$ 。BUN的非标准化系数为 0.108 , 显着概率为 $p=0.006$, 这意味着当BUN增加 $1 \mathrm{mg} / \mathrm{dL}$ 时, 皱纹增加 0.108 。 $\mathrm{R}^{2}$ 的解释力为 0.203 。结论: 这 是第一份基于经验数据揭示血糖和BUN（影响心血管疾病和糖尿病的已知因素）也影响面部波纹的报告。

关键词: 血糖, 血尿素氮, 钙阳离子, 氯离子, 皱纹 